\title{
Interdisciplinary Rehabilitation Chronic Pain Program, Benefits of Working under International Standards, Eight Years Experience in Argentina
}

\author{
Salvat $\mathrm{F}^{1 *}$, Parada Marcilla $\mathrm{M}^{1}$, Cervio $\mathrm{A}^{2}$, Amuchastegui $\mathrm{C}^{1}$, Sendon $\mathrm{M}^{1}$, Gimenez $\mathrm{J}^{1}$, Cruz $\mathrm{N}^{1}$, Nastri $\mathrm{M}^{1}$, Gordillo \\ $\mathrm{S}^{1}$, Quaglia $\mathrm{G}^{1}$, Tamashiro $\mathrm{M}^{1}$, Delia $\mathrm{V}^{1}$, Da Silva $\mathrm{V}^{1}$ and Pueyrredon $\mathrm{JH}^{1}$
}

${ }^{1}$ Neurology department, Raul Carrea Institute for Neurological Research, Argentina

${ }^{2}$ Neurosurgery department, Raul Carrea Institute for Neurological Research, Argentina

Submission: November 08, 2017; Published: January 25, 2018

*Corresponding author: Fernando Salvat, Neurology department, Raul Carrea Institute for Neurological Research, Montañeses 2325, Buenos Aires, Argentina, Tel: 00541157773200; Email: fsalvat@fleni.org.ar

\section{Abstract}

Traditionally, pain treatments have focused almost exclusively on reducing pain sensation, mostly through medication and physiotherapy. In this study we describe outcomes in patients treated applying interdisciplinary educational and therapeutic methods at FLENI's Interdisciplinary Outpatient Pain Rehabilitation Program (IOPRP), during an eight-year period. Between January 2006 and December 2014, 1176 patients received twice-weekly treatment at our center, each completing a total of 16 sessions. Batteries of self-reported questionnaires were administered at the beginning and end of the program, and follow up visits scheduled three months and one year after discharge. Five-hour treatment sessions included: clinical examination, physical and occupational therapy, cognitive and behavioral techniques for pain and stress management and nutrition education. 302 patients referred chronic cervical pain (25.7\%) and 874 chronic lumbar pain (74.3\%). Results of baseline IOPRP assessment scores in this population were as follows: Visual Analogue Scale (VAS) $5.66 \pm 0.07$, quality of life (SF36) $41.9 \pm 0.54$, subclinical insomnia (ISI) 11.31 \pm 0.26 , mild mood disturbance (BECK) $13.87 \pm 0.24$ and weight excess (BMI) $27.52 \pm 0.20$. At the end of the program, statistically significant improvement $(\mathrm{p}<0.05)$ was observed in every item mentioned above.

We conclude that application of an Interdisciplinary Program combining educational and therapeutic aspects under international quality standards will benefit patients, both regarding pain reduction and quality of life improvement, yielding sustained results, as observed during the study period reported.

Keywords: Chronic pain; Interdisciplinary; Rehabilitation

\section{Introduction}

Table 1: Study Participant Demographics.

\begin{tabular}{|c|c|c|}
\hline & $\mathbf{N}$ & $\mathbf{\%}$ \\
\hline Sex & & 31.1 \\
\hline Male & 366 & 68.9 \\
\hline Female & 810 & 25.7 \\
\hline Pain Diagnosis & 302 & 74.3 \\
\hline Cervical & 874 & Standard error \\
\hline Lumbar & Mean & 0.4 \\
\hline $\begin{array}{c}\text { Age (range 18-98 } \\
\text { years old) }\end{array}$ & 55.8 & \\
\hline
\end{tabular}

Chronic pain is a frequent and costly health problem worldwide, it's prevalence is increasing significantly, it is estimated that one in five people suffer from this debilitating chronic condition [1] that if left untreated can lead to emotional and physical complaints [2]. Traditional treatments focus exclusively on reducing pain sensations [3]. The aim of this study is to describe outcomes in patients treated at the Foundation for the Fight against Neurological Diseases in Childhood (FLENI) Interdisciplinary Outpatient Pain Rehabilitation Program (IOPRP) during an eight-year period, while working under international quality standards, accredited by the Commission on Accreditation of Rehabilitation Facilities (CARF).

\section{Materials and Methods}

We retrospective analyzed the medical records of 1176 patients with chronic cervical and low back pain, Table 1, between January 2006 and December 2014. Treatment 


\section{Open Access Journal of Neurology \& Neurosurgery}

consisted in a 16 session program of five-hour sessions twice a week, as well as home working applying every suggestion of the professional team (neurologists, traumatologist, neurosurgeon, psychologists, nutritionist, occupational therapists, nurse, administratives). Interventions were performed individually and in groups of 6 to 9 patients. All programs treatment included pain medication, physical and occupational therapy, as well as cognitive and behavioral techniques for pain and stress management. Information of each patient's functional and psychological status was collected through a battery of selfreported questionnaires test, Table 2 , at the beginning and again at the end of the program, and at the follow up at three and at twelve months after discharge.

Table 2: Wilcoxon Matched Pairs Test.

\begin{tabular}{|c|c|c|c|c|c|c|c|}
\hline \multirow{2}{*}{ Outcome } & \multicolumn{2}{|c|}{ Initial } & \multicolumn{2}{|c|}{ Final } & \multirow{2}{*}{$\mathbf{N}$} & \multirow{2}{*}{$\%$ Variation } & \multirow{2}{*}{$\mathbf{p}<$} \\
\hline & Mean & SEM & Mean & SEM & & & \\
\hline VAS & 5.6 & 0.1 & 3.7 & 0.1 & 919 & -66 & 0.0001 \\
\hline RMT & 10.6 & 0.2 & 7.5 & 0.2 & 730 & -71 & 0.0001 \\
\hline ODI & 29.9 & 0.6 & 20.9 & 0.6 & 743 & -70 & 0.0001 \\
\hline SF36PF & 50 & 0.8 & 60.1 & 0.8 & 863 & 20 & 0.0001 \\
\hline SF36PR & 19.9 & 1.1 & 47.5 & 1.4 & 864 & 138 & 0.0001 \\
\hline SF36BP & 28.2 & 0.6 & 49.9 & 0.7 & 863 & 77 & 0.0001 \\
\hline SF36GH & 50 & 0.7 & 60.7 & 0.6 & 864 & 21 & 0.0001 \\
\hline SF36V & 38.9 & 0.7 & 53 & 0.6 & 864 & 36 & 0.0001 \\
\hline SF36SF & 50.8 & 0.9 & 69.7 & 0.8 & 864 & 37 & 0.0001 \\
\hline SF36ER & 43.7 & 1.4 & 66.5 & 1.2 & 864 & 52 & 0.0001 \\
\hline SF36SMH & 53.8 & 0.7 & 67.3 & 0.6 & 863 & 25 & 0.0001 \\
\hline SF36 total & 42 & 0.6 & 58.9 & 0.6 & 926 & 40 & 0.0001 \\
\hline ВECK & 13.8 & 0.3 & 8.1 & 0.2 & 928 & -59 & 0.0001 \\
\hline BPS & 6.6 & 0.1 & 5 & 0.1 & 817 & -76 & 0.0001 \\
\hline HAQ20 & 0.8 & 0 & 0.6 & 0 & 856 & -71 & 0.0001 \\
\hline ISI & 11.1 & 0.3 & 7.6 & 0.3 & 513 & -69 & 0.0001 \\
\hline
\end{tabular}

\section{Statistics}

Quantitative data was expressed as mean \pm SEM. Normally distributed data were tested using one way ANOVA, and repeated measures ANOVA to compare beginning and end of the study. For non-normally distributed data, Wilcoxon matched pair test was used to compare variables and Mann-Whitney U test to compare diagnosis and sex. CSS/Statistica package version 7.0 (StatSo, Tulsa, USA) was used in the analyses, and $\mathrm{P}<0.05$ regarded as statistically significant.

\section{Results}

During this period of 8 years, 1176 chronic pain patients completed the IOPRP and comprise the sample for which results are presented: (Figure 1-4).

\section{Discussion}

According to the International Association for the Study of Pain (IASP), "Pain" is defined as an unpleasant sensory and emotional experience associated with actual or potential tissue damage, or described in terms of such damage [4]. Chronic pain become a costly health-care problem, not only in terms of work absences and lost productivity but also in terms of medical care expenses [5]. Chronic pain can lead to serious emotional and physical complaints such as depression, sleeping disorders, immune suppression, eating disorders, cognitive impairments and other long-term deleterious effects in life quality [2].

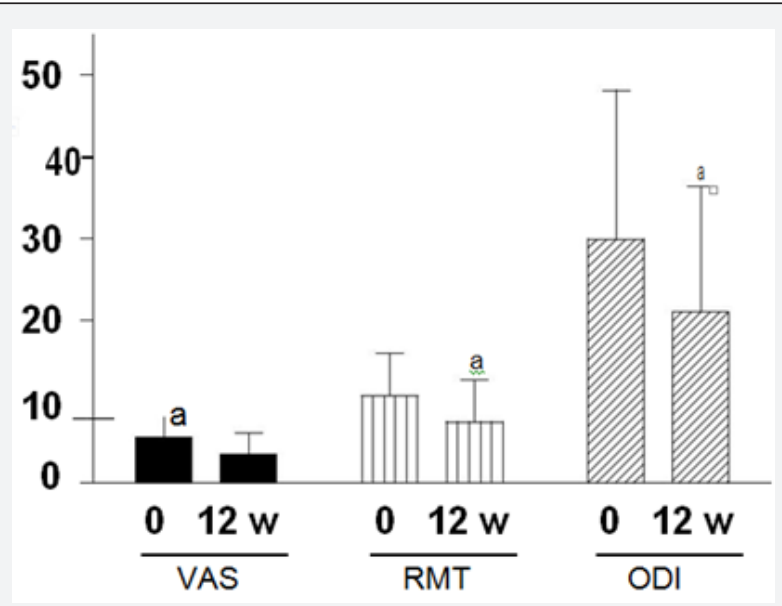

Figure 1: Initial VAS, RMT, ODI values obtained, and those observed at the end of the IOPRP: a: $p<0.0001$ vs 0 weeks.

We develop an interdisciplinary pain rehabilitation program (IOPRP) that provides significant outcomes, working under international quality standards since 2004, by a worldwide accreditor of health and human service providers [6]. Our method is based in the incorporation of medical, psychological, 
functional, and physical treatments in an integrated format, providing rehabilitation treatment for adults with low back pain, neck pain, musculoskeletal disorders, and other chronic pain conditions. The focal goal of our program is enhance the ability to cope with and manage pain while restoring function and quality of life. Our results showed improved on quality of life outcomes, Figure 4, pain was reduced by 55\%, insomnia, Figure 3 , by $30 \%$ and curiously, depression, which initially was higher in women, improved by the end of the program, to levels similar to those observed in men. The average pain improvement, Figure 1 , in this study was within the range of expected $14 \%$ to $60 \%$ pain improvement reported in the literature [7].

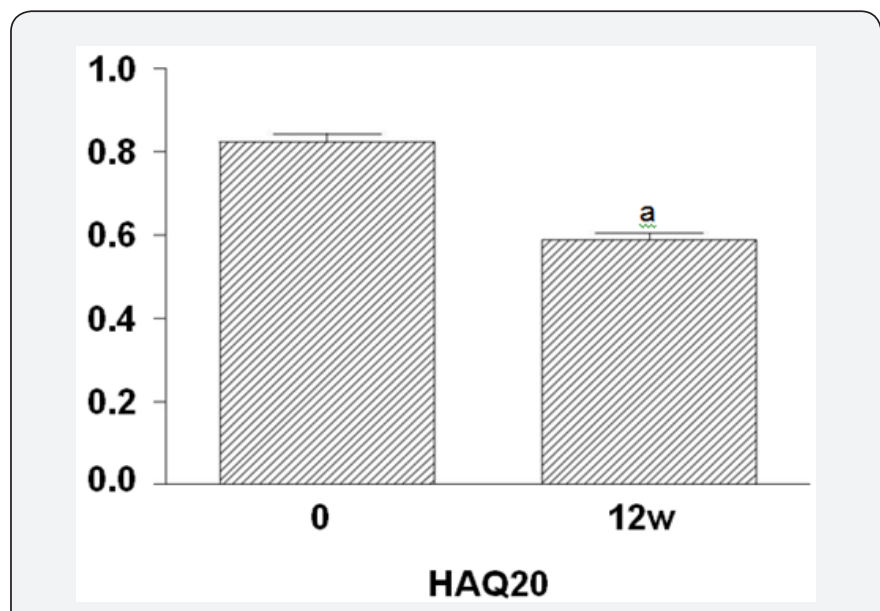

Figure 2: $H A Q 20$ values obtained at the beginning and end of the IOPRP (12 weeks). a: $p<0.0001$ vs 0 weeks.

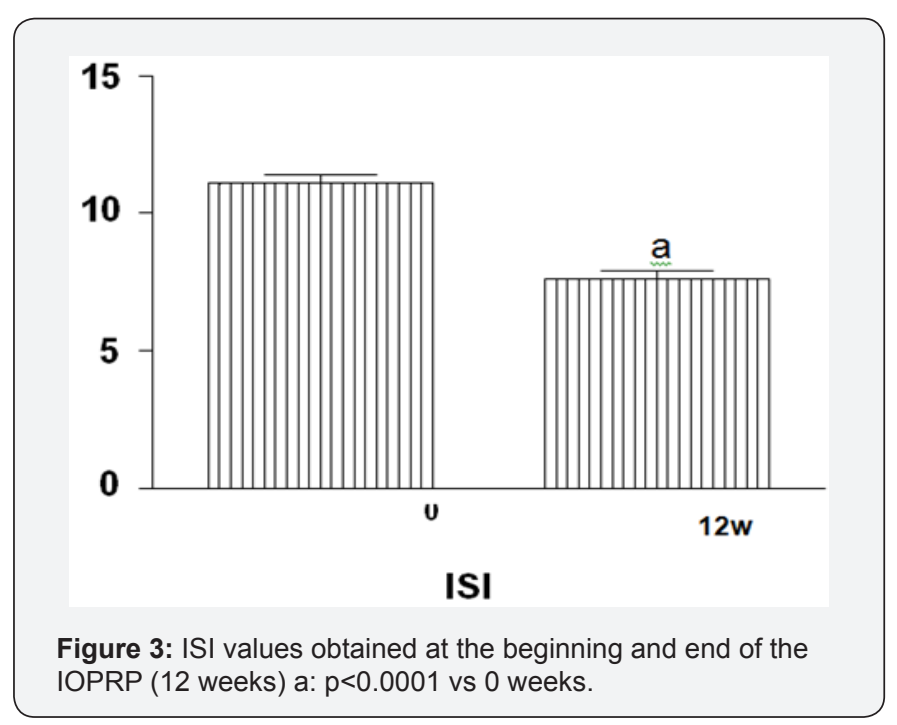

At the end of the program patients expressed satisfaction not only with services offered during treatment, but also with outcomes obtained. Managing to adopt cognitive-behavioural strategies for pain management seems to correlate with reduction in the need for medication, maximizing of function by addressing wellness, and the opportunity to create a healthy lifestyle, and learning to cope with pain as it is to reduce the level of pain, regardless of the degree of pain improvement they experienced.

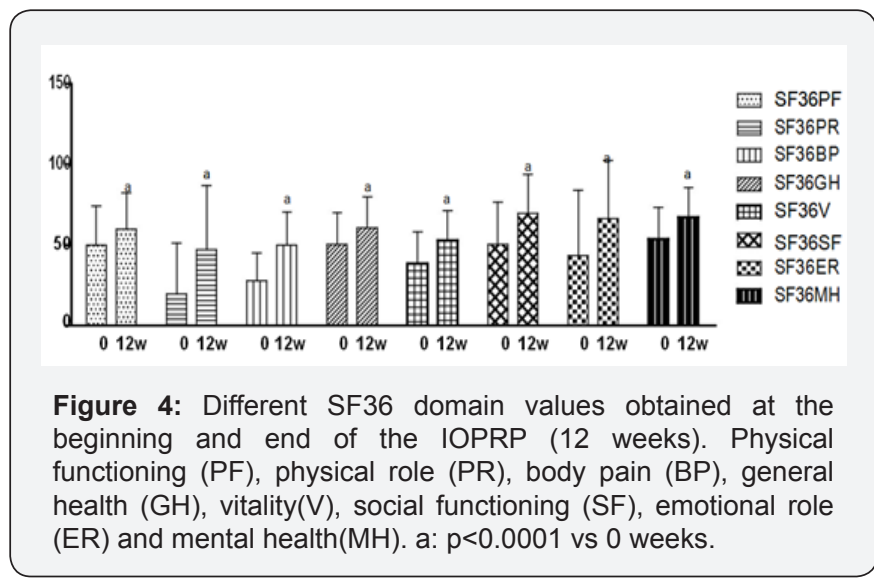

\section{Limitations}

Control group (traditional treatment) was not taken into account on this work and limits the conclusions that can be drawn from the results. During follow-up, response rate at 12 weeks was $43 \%$, but only $10 \%$ at one year. This lack of adherence to follow up must be taken into account for further research.

\section{Conclusion}

Results indicated not only that application of an IOPRP is feasible in Argentina, but also that results were uniform and sustained throughout the study period. Based on our experience, we encourage other centers to treat chronic pain in an interdisciplinary fashion, following international quality standards.

\section{Referances}

1. Catala E, Reig E, Artes M, AliagaL, Lòpez JS, et al. (2002) Prevalence of pain in the Spanish population: Telephone survey in 5000 homes. Eur J Pain 6(2): 133-140.

2. Gerdle B, Bjork J, Henriksson C, Bengtsson A (2004) Prevalence of current and chronic pain and their in uences upon work and healthcareseeking: A population study. J Rheumatol 31(17): 1399-1406.

3. Le Pen C, Reygrobellet C, Gerentes I (2005) Financial cost of osteoarthritis in France: a "COART" French study. Joint Bone Spine 72: 567-570.

4. Merskey H (1994) Logic, truth and language in concepts of pain. Qual Life Res 3: S69-S76.

5. Mansour AR, Farmer MA, Baliki MN, Apkarian AV (2014) Chronic pain: a role of learning and brain plasticity. Restor Neurol Neurosci 32(1): 129-139.

6. Joint Commission and CARF (1996) establish combined survey process for rehabilitation hospitals. Jt Comm Perspect 16(6): 11.

7. Gatchel RJ, Okifuji A (2006) Evidence-based scientific data documenting the treatment and cost-effectiveness of comprehensive pain programs for chronic nonmalignant pain. J Pain 7(11): 779-793. 
This work is licensed under Creative Commons Attribution 4.0 Licens

DOI: 10.19080/OAJNN.2018.06.555700
Your next submission with Juniper Publishers will reach you the below assets

- Quality Editorial service

- Swift Peer Review

- Reprints availability

- E-prints Service

- Manuscript Podcast for convenient understanding

- Global attainment for your research

- Manuscript accessibility in different formats

( Pdf, E-pub, Full Text, Audio)

- Unceasing customer service

Track the below URL for one-step submission https://juniperpublishers.com/online-submission.php 